\title{
FONDASI KRITIK KARYA SENI DARI PERSPEKTIF ESTETIKA ANALITIS EMANSIPATORIS NOËL CARROLL
}

\begin{tabular}{l|l} 
Mardohar B.B. Simanjuntak & Faculty of Philosophy
\end{tabular}

Parahyangan Catholic University

Bandung, Indonesia

\section{Abstract:}

Defining what an artwork is has been a recurrent theme in aesthetics, or to be more specific, in the philosophy of art. Yet this is proven to be no simple matter. Thus finding the definition of art has proven to be an elusive undertaking as works of art have always kept on eluding one definition after another. A strong definition might have proven to be illusory. An analytic aesthetician, Noël Carroll has undertaken a complex, if not ambitious, project opting to refute this conundrum in aesthetics by proposing another perspective that stems not from metaphysics but an epistemological one. He managed to show analytically that the epistemological approach is far less problematic and even offers a string of advantages at the praxis level. Carroll completed his proposal by revising two of the most powerful definition of art, that is, the Kantian aesthetic experience and the Levinsonian historical definition of art in those he emancipated the most essential foundation disinterestedness coined by Immanuel Kant, and set the modified definition in a trail of historical correctness. The mix between these two strong elements has amalgamated in a new breed proposed by Carroll in that he labels it historical narrative. This, for Carroll, is a better option over endless disputes over the speculated essence of an artwork and its criticism.

Keywords:

aesthetic experience $\bullet$ disinterestedness $\bullet$ design appreciation $\bullet$ historical narrative Karakter Problematis Upaya Pendefinisian Karya Seni 
Kelenturan ranah estetika kadang-kadang menjadi bumerang dan menyulitkan gerak dan geliat kajian filsafat ini sendiri. Di satu sisi, kemampuannya untuk masuk dan menggamit berbagai macam aspek yang saling bertentangan menjadi semacam keunggulan mutlak yang tidak dimiliki oleh ranah kajian filsafat lainnya. Namun, di sisi lain, kelenturan semacam ini juga sekaligus kelemahannya: estetika menjadi terlalu amorf untuk bisa mengambil asumsi bentuk apapun. Bagi mereka yang hidup dan berkarya dalam wilayah seni, sebuah medan yang menjadi objek formal estetika, ini menjadi pedang bermata ganda. Para seniman, misalnya, dapat dengan mudah masuk ke wilayah apapun bahkan hingga ke ranah subliminal yang jelas ada di luar kemampuan inderawi manusia. Namun, kelegaan semacam ini juga menjadi semacam tekanan karena akhirnya seakan-akan tidak memiliki jangkar yang tertancap kokoh untuk menegaskan status artistik karya.

Sejarah seni rupa (fine art) menunjukkan bahwa berkali-kali para seniman terpaksa dihadapkan pada situasi kontroversial: "entah karya mereka seni atau bukan seni". Dalam sejarah seni rupa barat di abad kedua puluh, setidaknya tercatat dua karya yang sangat 'bermasalah' yang sekaligus mengubah seluruh tatanan lanskap seni rupa: Fountain dari Marcel Duchamp, dan Brillo Box dari Andy Warhol. Karya yang pertama adalah sebuah upaya dekonstruksi frontal yang begitu problematis dan sangat ofensif bagi dunia seni di masa itu. Duchamp hanya membeli pispot dinding dan menandatanganinya dengan "R. Mutt" sebelum memasukkannya ke pameran seni rupa pada 1917. Tidak kalah ofensif dan problematisnya, 47 tahun kemudian Andy Warhol membuat tujuh belas replika kotak sabun "Brillo" dengan tinggi hampir setengah meter dan memamerkannya di sebuah galeri.

Estetika memang berurusan dengan spektra yang sangat luas dan serba tidak pasti ini, dan sebagai konsekuensinya, salah satu tantangan terberat disiplin yang berurusan dengan aesthétê ini adalah memetakannya. Membuat peta estetika hampir tidak ada bedanya dengan memetakan bukit-bukit pasir di Sahara yang dalam semalam bisa berpindah tempat ratusan meter. Mencari sebuah pola yang teratur dalam estetika adalah hampir sebuah kemustahilan karena yang dipetakan sudah selalu dan tidak akan pernah berhenti bergerak. Pola ini bersifat elusif, licin, karena setiap kali disergap dengan sebuah definisi, selalu ada sembulan ragam atau genre 
karya yang lolos dari upaya pendefinisian yang paling rapat sekalipun. Upaya mengkonstruksi sebuah definisi karya seni dalam estetika, dengan demikian, lebih cocok bila diibaratkan dengan memetakan alur migrasi hewan-hewan migratoris yang berpatokan pada medan magnetis bumi atau penanda-penanda di sekitar garis pantai atau konstelasi bintang-bintang di langit. Misi inilah yang tampaknya diemban oleh Noël Carroll.

Sebagai seorang filsuf dari tradisi analitis Anglo-Saxon, Carroll cukup konsisten di wilayah estetis. Filsuf yang aktif menulis di bidang estetika atau filsafat seni terutama filsafat film ini dikenal lewat karya-karyanya seperti Philosophy of Art, A Contemporary Introduction, The Philosopby of Motion Picture, Beyond Aesthetics: Philosophical Essays dan On Criticism. Carroll termasuk estetikus yang paling produktif dalam merumuskan ulang definisi-definisi tentang apa itu seni. Sebagai murid dari George Dickie, estetikus analitis yang membidani lahirnya the institutional theory of art (teori institusional tentang seni) dengan konsep the art circle-nya, dan juga teman sejawat Arthur Danto, estetikus analitis yang memberikan fondasi filosofis bagi Brillo Box lewat artikel seminalnya, "The Artworld", Carroll memperkuat posisinya dalam khasanah diskursus estetika lewat pendekatan narasi historisnya (historical narrative) yang merupakan sebuah bentuk revisi konsep pengalaman estetis dan definisi historis tentang seni (the historical definition of art) yang digagas oleh Jerrold Levinson.

Tulisan ini bertujuan memberikan gambaran tentang upaya Carroll dalam memetakan sembulan acak dan mutakhir medan seni rupa. Ini akan tidak mudah, karena, misalnya, bagi filsuf Neo-Wittgensteinian yang menjangkarkan filsafatnya pada Philosopbical Investigation Ludwig Wittgenstein, upaya seperti ini terkesan sia-sia. Estetikus anti-theory semacam ini mewarisi sikap pesimistis estetikus analitis Morris Weitz yang tertera tegas dalam artikel seminalnya "The Role of Theory in Aesthetics". Meskipun demikian, di tengah pesimisme semacam ini Carroll justru menunjukkan sikap optimistisnya tentang kemungkinan untuk mendefinisikan karya seni.

Untuk dapat memahami optimisme dan intensi emansipatoris Carroll, saya akan mulai dengan membahas secara ringkas pokok-pokok utama bangun konstruksi estetika analitis Carrollian. Di bagian ini saya akan mengangkat peta besar filsafat seni yang dipaparkan Carroll dalam karyanya Philosophy of Art, A Contemporary Introduction, ketika Carroll secara eklektis 
memetakan alur dialektis upaya pendefinisian karya seni yang dimulai dari Plato hingga dimutakhirkan Levinson. Di bagian berikutnya, saya akan mengangkat upaya epistemologis Carroll yang ditajamkannya dengan membedah sebuah konsep yang sangat fundamental dalam estetika: pengalaman estetis (aesthetic experience) yang diulas secara komprehensif dalam Beyond Aesthetics: Philosophical Essays dan beberapa tulisan lainnya. Dengan meniti alur diskursus dari yang umum dan abstrak hingga ke yang spesifik semacam ini, orang akan mampu menyelami solusi Carroll terhadap salah satu masalah perenial dalam estetika: mencari definisi karya seni dan mengkonstruksi kritik-kritik terhadapnya.

\section{Mencari Definisi Seni: Menyelami Sumur Tanpa Dasar}

Upaya untuk menemukan sebuah definisi karya seni yang inklusif (yang dapat menjaring seluruh varian karya seni) dapat disejajarkan dengan mencari esensi terdalam estetika. Estetika adalah perkara aisthanomai (to sense), namun locus tempat estetika menggeliat adalah seni ${ }^{1}$. Bagi Carroll, estetika lahir dari tangan Plato dan Aristoteles, menemukan identitasnya di tangan Immanuel Kant dan G.W.F. Hegel, dan dewasa di tangan siapapun yang merasa peduli terhadap kehadiran seni dalam kehidupan manusia dan risih terhadap perlakuan semena-mena terhadapnya. Namun, Carroll tidak membagi upaya tanpa kenal henti untuk menjawab pertanyaan "Apa itu seni?" itu ke dalam rangkaian pemikiran filsafat berdasarkan filsuf-filsuf tertentu. Sebaliknya, ia memilih untuk masuk ke dalam bendera yang mereka kibarkan. Bagi Carroll, proyek kolosal filsafat yang sudah berlangsung selama setidak-tidaknya dua ribu tahun lebih ini bisa dikelompokkan ke dalam lima bagian besar: (1) seni dan representasi, (2) seni dan expresi, (3) seni dan bentuk, (4) seni dan pengalaman estetis, serta (5) seni, definisi dan identifikasi.

Klasifikasi impersonal semacam ini memudahkan Carroll untuk tidak terjebak ke dalam perkembangan pemikiran para filsuf yang seringkali tidak menarik garis batas yang tegas dalam pemikirannya. Sebagai contoh, filsuf Inggris R.G. Collingwood mulai dengan jalur Hegelian di titik awal pemikirannya, namun pada perkembangan selanjutnya Collingwood bergeser ke wilayah Kantian. Contoh klasik lain dalam dunia filsafat adalah tentang perubahan dramatis pemikiran Wittgenstein dari Tractatus Logico Philosophicus ke Philosophical Investigations. Karakter evolusi pemikiran yang 
subtil semacam ini akan menyulit pengkaji estetika untuk menemukan klasifikasi yang dapat dengan leluasa memberikan gambaran yang utuh tentang perkembangan estetika dalam tahapan terkininya. Carroll seakanakan tidak ingin terjebak terseret terlalu jauh ke dalam ambiguitas palungpalung pemikiran tunggal-personal semacam ini. Singkatnya, Carroll mencoba untuk menerapkan sebuah analisis tematis untuk proyek ambisiusnya, dan memilih untuk sedapat mungkin memberikan gambaran yang tegas dan menyeluruh tentang dinamika pencarian definisi karya seni. Berikut pembahasan sekilas kelima klasifikasi yang ditawarkan Carroll.

Pertama, tentang seni dan representasi, Carroll mencatat bahwa upaya kolosal filsafat untuk mengidentifikasi seni sebagai sebuah elemen fundamental diawali terutama oleh Plato dengan seni sebagai sebuah kegiatan imitasi, meniru (mimesis), dan Aristoteles dengan katarsis dan aisthesis. Menariknya, Plato dalam Politeia mulai dengan mencurigai seni yang kental dengan imitasi yang menurutnya memiliki konsekuensi mendalam dan serius dalam kehidupan sosial, dan bahkan demikian serius sehingga imitasi, yang bagi Plato adalah sebuah simulasi kemunculan (the simulation of appearance), cenderung berbahaya karena "appearances appeal to the emotions and [...] stirring up the emotions is socially dangerous" (kemunculan mempengaruhi emosi dan menyibak emosi adalah sesuatu yang sangat berbahaya bagi kehidupan sosial). ${ }^{2}$

Meskipun demikian, Aristoteles ternyata tidak terlalu sependapat dengan kekhawatiran Plato. Baginya, Plato terlalu berlebihan dalam menyikapi karya seni terutama drama. Menurut Aristoteles, tragedi, misalnya, yang memang memicu rasa kasihan dan ketakutan, adalah sebuah elemen penting, sebab lewat kegiatan artistik semacam itulah manusia bisa mencapai katarsis, sebuah upaya melepaskan gejolak emosi yang jenuh memadati 'kepala' seseorang. Alih-alih curiga, Aristoteles justru menyambut seni, dalam hal ini drama, dengan alasan bahwa seni adalah wajah miniatur kehidupan itu sendiri. ${ }^{3}$

Dalam perkembangan selanjutnya, konsep imitasi berkembang menjadi representasi. Singkatnya, seturut jalur pemikiran ini, sebuah karya dapat dikategorikan sebagai karya seni oleh karena kemampuannya merepresentasikan yang lain. Representasi semacam ini memberi penekanan pada isi (content) sebagai elemen primer sebuah karya seni, sebab bentuk adalah alat bantu bagi audiens untuk memahami makna (meaning) 
hasil kerja sang seniman, yang tiada lain adalah representasi dari realitas. Atas dasar itu, bentuk (form) hanyalah sesuatu yang sifatnya sekunder.

Meskipun demikian, bagi Carroll gagasan tentang seni sebagai representasi yang bertahan selama hampir dua ribu tahun sampai kelahiran Romantisisme, memiliki titik lemah yang sangat fatal. Menurutnya, baik representasi maupun varian lanjutnya seperti Neo-representasi memiliki masalah yang kurang lebih sama: "many works of art [...] are not representations" (banyak karya seni bukanlah representasi). ${ }^{4}$ Seni dan representasi, dengan demikian, masih terlalu eksklusif untuk merangkum karya seni dalam sebuah klasifikasi utuh. Masalah ini kemudian dicoba untuk dijawab oleh para estetikus dengan menggeser titik berat definisi ke ekspresi.

Kedua, tentang seni dan ekspresi, Carroll mengatakan bahwa sekalipun representasi dan ekspresi masih mendasarkan metodenya pada supremasi isi atas bentuk, terdapat perbedaan mendasar di antara keduanya. Seni sebagai representasi pada dasarnya berbicara tentang refleksi realitas eksternal yang muncul terpantul dari karya dengan peran seniman sebagai ilmuwan yang berusaha 'menangkap' realitas. Sebaliknya, seni sebagai ekspresi adalah perkara proyeksi realitas internal yang menempatkan peran seniman sebagai komunikator yang berusaha 'membahasakan' hal-hal dalam diri manusia yang sulit diartikulasikan. Di sini karya seni adalah sarana mentransfer emosi dari dalam ke luar, membuat audiens dari sebuah karya merasakan apa yang dirasakan oleh sang seniman.

Meski demikian, masalah terbesar proses transfer ini adalah perbedaan muatan emosi yang ditransfer. ${ }^{5}$ Ini berarti, menurut Carroll, "the artist and the audience are not feeling the same thing" (seniman dan audiens [belum tentu] merasakan hal yang sama); lagi pula, posisi ini semakin bermasalah karena "[a]rt need not be about feeling; it may take ideas, including the play of ideas, as its subject" (seni tidak melulu tentang perasaan [emosi]; seni juga bisa bicara tentang ide, termasuk permainan ide, sebagai subjeknya). ${ }^{6}$

Pada saat ekspresi kemudian berevolusi menjadi semacam metafora yang sifatnya subtil yang juga kental dengan dimensi antropomorfis, tidak semua karya seni dapat mengasumsikan posisi metaforis. Sebuah karya seni bahkan bisa sangat harfiah tanpa muatan emosi sama sekali, seperti yang dikatakan Carroll, "ascribing anthropomorphic terms to 
such artworks should not be misunderstood as a matter of an optional, ornamental, metaphorical description[;] rather, it is literal" (memberikan label antromorfik semacam ini ke karya seni tidak seharusnya dipahami sebagai sesuatu yang opsional, ornamental, atau metaforik; lebih tepatnya, karya semacam itu adalah sesuatu yang literal). ${ }^{7}$

Lagi-lagi, ekspresi sebagai esensi karya seni ternyata masih terlalu eksklusif. Masih banyak karya seni yang bisa dikatakan steril dari ekspresi emosional. Ini memberikan tantangan kepada para estetikus karena ternyata elemen isi dari sebuah karya tidak cukup komprehensif untuk menangkap ragam objek estetis yang tidak pernah berhenti berevolusi. Perkembangan ini selanjutnya membawa para pengkaji estetika untuk melihat kemungkinan lain yang selama ini dianggap sekunder: bentuk.

Ketiga, tentang seni dan bentuk, Carroll mengatakan bahwa ketidakmampuan representasi dan ekspresi untuk merangkum karya seni dalam sebuah definisi yang inklusif kemudian ditanggapi oleh para filsuf dengan mengambil posisi Neo-kantian yang memberi penekanan serius pada bentuk, dan sebaliknya, isi dianggap sebagai sesuatu yang sekunder. Sebuah label baru pun dimunculkan untuk memberikan status baru pada bentuk: significant form (bentuk signifikan), sebagai tolak ukur universal yang baru untuk menggantikan representasi dan ekspresi. ${ }^{8}$ Penekanan pada bentuk ini merupakan jawaban atas ketidaksanggupan isi, yang merupakan tema utama representasi dan ekspresi, untuk menjadi jangkar definisi seni. Maksudnya, bila karya seni tidak selalu tentang representasi ataupun ekspresi, setidak-tidaknya keduanya memiliki bentuk signifikan yang sama. Inilah ide dasar di balik konsep significant form semacam ini. Meski demikian, mengabaikan isi tidak banyak membantu untuk membuat sebuah definisi yang universal karya seni, karena kebanyakan karya tidak bisa dipisahkan dari isinya. Dengan kata lain, bentuk signifikan tidak cukup untuk memahami semua karya seni.

Formalisme semacam ini akhirnya diteruskan oleh Neo-formalisme, yang tetap mengusung tema yang sama, namun memberikan semacam referensi pada isi. Carroll mencatat bahwa bagi kaum Neo-formalis "form [...] is the mode of presentation of its meaning" (bentuk adalah sebuah tanda kehadiran maknanya). ${ }^{9}$ Doktrin seperti ini berupaya 'mengawinkan' bentuk dan isi, dan demikianlah para filsuf Neo-formalis berharap 
untuk dapat menyelesaikan seluruh kendala yang mengganjal proses pendefinisian karya seni. Meskipun sudah jauh lebih baik dari perspektifperspektif sebelumnya, bahkan dari formalisme, masih ada masalah yang mengganjal: neo-formalisme hanya sanggup menjangkau kategori karya seni yang dicap bagus. Artinya, seni dan bentuk masih bersifat eksklusif, karena sebuah karya seni 'buruk' pun tetap adalah karya seni.

Ini berarti perubahan titik sentral pembahasan ke bentuk pun gagal memberikan alternatif yang lebih komprehensif daripada representasi dan ekspresi. Lagi-lagi, upaya untuk menambatkan definisi seni pada bentuk ataupun jalinan antara bentuk dan isi masih belum bisa mengikis karakter eksklusif semacam itu. Karakter problematis yang disandarkan pada objek seni, baik isi (representasi dan ekspresi) maupun bentuk dan persinggungan antara isi dan bentuk, membuat para estetikus akhirnya berpaling pada pengamat (audiens) sebagai sebagai tambatan dalam upaya mendefinisikan karya seni.

Keempat, tentang seni dan pengalaman estetik, Carroll memberikan catatan bahwa pada dasarnya, di titik inilah estetika "yang sesungguhnya lahir". ${ }^{10}$ Boleh dikatakan bahwa yang menjadi fokus utama adalah karya seni itu sendiri sebagai sebuah objek estetis, baik dari sisi isi, bentuk, maupun jejalin di antara keduanya, maka lebih tepat untuk mendefinisikan upaya pendefinisian semacam itu dalam kotak filsafat seni. Lebih lanjut Carroll mengatakan: "[a]esthetics is broader than the philosophy of art since it studies nature as well[;] [a]nd a philosophy of art might define "art" without reference to aesthetic experience or audience reception" (estetika lebih luas daripada filsafat seni karena estetika juga mengkaji tentang alam [sebagai elemen artistik]; dan filsafat seni bahkan dapat mendefinisikan 'seni' tanpa sama sekali menyinggung tentang pengalaman estetis atau penerimaan audiens terhadap karya seni). ${ }^{11}$

Tampaknya tidak berlebihan bahwa F.W. Nietzsche mengomentari Kant, salah satu pilar estetika yang 'membaptis' revolusi Kopernikan ke arah pengalaman estetik, dengan mengatakan bahwa "Kant, instead of approaching the problem of aesthetics from the experiences of the artist (the creator), meditated over art and beauty merely from the standpoint of the "spectator" (Kant, alih-alih mencoba mengkaji masalah estetika dari pengalaman sang seniman [sebagai pencipta], lebih memilih untuk merenung seni dan keindahan dari perspektif sang 'pengamat'). ${ }^{12}$ Mungkin 
tidak berlebihan pula untuk mengatakan bahwa tidak akan ada estetika tanpa pengalaman estetis. Perubahan kali ini dalam sistem pemetaan yang diajukan Carroll memang fundamental, dan Carroll sendiri akhirnya menjangkarkan tawaran pendefinisiannya pada pengalaman estetis semacam ini.

Pokok paling penting seni dan pengalaman estetis, terutama yang dimasukkan ke dalam kategori definisi estetik tentang seni (the aesthetic definition of art), adalah tentang sebuah sikap mental kontemplatif yang muncul saat pengamat berhadapan dengan sebuah karya seni. Dengan kata lain, "[a]rtworks are primarily esteemed by audiences as potential sources of [...] aesthetic experiences" (karya seni utamanya dianggap oleh audiens sebagai sumber-sumber potensial dari pengalaman estetik). ${ }^{13}$ Perenungan semacam ini hanya mungkin dilakukan bila ada intensi dari sang seniman, yang tidak lain dari "a mental state that is itself comprised of at least two constituent types of mental states: beliefs and desires" (sebuah sikap mental yang terdiri atas dua macam sikap mental: kepercayaan dan hasrat [motivasi]). ${ }^{14}$ Dengan kata lain, sebuah karya layak diberi status sebuah karya seni bila diciptakan dengan intensi dari sang seniman dan sanggup memberikan pengalaman estetik kepada para pengamat.

Meski demikian, bahkan pengalaman estetika pun belum bisa keluar dari klaim eksklusivisme yang mendera tiga pola pendekatan sebelumnya. Ganjalan terbesar yang 'diderita' oleh pengalaman estetis terletak pada sebuah konsep yang sangat problematis: disinterestedness (ketanpapamrihan), yang boleh dikatakan 'mementahkan' semua usaha pendefinisian seni. Sebabnya ialah, secara eksplisit Carroll mencatat bahwa "many artworks are produced with religious and political purposes in mind" (banyak karya seni yang dibuat berdasar kepentingan religius dan politis). ${ }^{15}$ Bahkan, Carroll menegaskan bahwa "so many artists are self-conciously explicit [sic] about their opposition to the concept of disinterestedness" (begitu banyak seniman dengan terbuka dan sadar mengemukakan penolakan mereka terhadap konsep ketanpapamrihan). ${ }^{16}$ Menariknya, ketanpapamrihan sebagai rintangan terakhir dalam mengkonstruksi sebuah definisi karya seni yang komprehensif tidak perlu ditanggalkan. Ketanpapamrihan harus diklarifikasi dan ditempatkan ulang. Pada titik inilah dapat dilihat karakter analitis-emansipatoris bangun estetik Carroll. Meski begitu, sebelum sampai pada pendekatan yang diambil oleh Carroll, 
akan dilihat satu upaya lagi yang ditempuh di luar jalur pengalaman estetis: karakter pluralitas definisi karya seni.

Kelima, tentang seni, definisi dan identifikasi, Carroll menjelaskan bahwa, seperti yang sempat saya singgung di atas, mazhab terakhir yang mencoba mendefinisikan seni sampai pada kesimpulan mengenai tidak mungkin mendefinisikan seni. Carroll bahkan mengutip secara lengkap pernyataan Weitz dalam artikel seminalnya: "Art' is an open concept" ('Seni' adalah sebuah konsep terbuka). Prinsip ini terpatri kuat dalam pemikiran para filsuf analitis yang ada dalam barisan Neo-Wittgensteinian, sehingga mereka memilih untuk tidak mendefinisikan apapun.

Solusi yang lantas ditawarkan oleh kaum Neo-Wittgensteinian menurut Carroll adalah "[a new artwork] shares some similarities with some of our paradigms in some respects and other similarities with other paradigms in other respects" ([sebuah karya seni yang baru dan berbeda dari sebelumnya] memuat kemiripan dengan paradigma yang satu dalam beberapa hal dan dengan paradigma yang lain dalam hal yang lain). ${ }^{17}$ Kata kuncinya bagi kaum Neo-Wittgensteinian adalah family resemblance (kemiripan keluarga). Dengan kata lain, sebuah karya dapat dianggap sebagai karya seni bila karya tersebut memiliki kemiripan dengan karya-karya yang ada sebelumnya. Akan tetapi, alih-alih menjadi alternatif terutama bagi definisi yang diajukan oleh pengalaman estetik, model semacam ini membuat "bola salju pendefinisian karya seni”' menjadi 'liar' dan tak terkendali. Alasannya, model pendefinisian semacam ini terlalu longgar.

Akibatnya, gagasan itu sudah "layu sebelum berkembang", dan tidak berumur panjang, setidak-tidaknya pengalaman estetis masih cukup kuat bertahan setelah kira-kira dua ratus tahun. Dua alternatif utama segera masuk dan menggantikan, atau merevisi, gagasan kontroversial ini: pendekatan teori institusional tentang seni (the institutional theory of art) yang diusung George Dickie, dan definisi historis tentang seni (the historical definition of art) yang digagas oleh Jerrold Levinson. Carroll mencatat bahwa bagi Dickie, bila definisi seni tidak dapat dijangkarkan di karya seni (isi, bentuk serta gabungan keduanya) dan di pengamat, lingkungan tempat karya senilah yang menjadi wasitnya. Habitat tempat sebuah karya seni 'hidup', karenanya, adalah sebuah institusi. Sehingga seturut jalur yang dipilih Dickie, sebuah karya seni adalah apa yang dianggap karya sen oleh lingkungan tempat tinggalnya, yang terdiri atas, misalnya, seniman, 
kolektor karya seni, galeri seni, kritikus seni, dan balai lelang karya seni.

Pendekatan institusional semacam ini kelihatan mumpuni, namun justru membawa kelemahan pada kata 'institusi' itu sendiri. Singkatnya, menurut Carroll, konsep 'institusi' yang diajukan oleh Dickie terlalu longgar, dan bahkan begitu longgar sehingga institusi semacam ini tidak memiliki titik tumpu yang jelas. Bahkan, lanjut Carroll, fondasi utama "institusi seni' adalah seniman yang 'melantik' dirinya sendiri menjadi seniman: selfelected $^{18}$ yang jelas merupakan sebuah batasan sirkular, yakni bahwa karya seni dianggap sebagai karya seni karena seniman menganggapnya sebagai sebuah karya seni.

Teori institusional tidak lebih baik daripada doktrin yang diajukan oleh para filsuf Neo-Wittgensteinian. Bisa diduga bahwa posisi ini segera memicu kemunculan sebuah posisi baru yang mencoba mengatasi fondasi yang rapuh semacam ini. Levinson kemudian melihat bahwa dari keseluruhan upaya untuk mendefinisikan seni diletakkan dalam kerangka ahistoris, sementara sejarah sendiri adalah sumber pengetahuan tentang perkembangan seni, dan sejarah tidak pernah mengalami masalah untuk 'menyambut' kelahiran karya seni yang baru, yang bahkan asing sama sekali.

Carroll melihat bahwa dalam pemahaman Levinson, ada koherensi antara karya seni yang satu dengan yang lain dalam sejarah. Dengan demikian, seni tidak berbeda dari "a coherent body of artifacts" (sebuah wujud koheren berbagai artefak). ${ }^{19}$ Di sini Levinson mengoreksi posisi 'wasit' yang terlalu longgar dalam pendekatan yang diambil Dickie: yang menjadi penentu dari karya seni atau tidaknya sesuatu adalah "art-regard condition”, yakni syarat yang sudah selalu ada dalam sejarah karya seni. Ini berarti bagi Levinson sejarah tentang karya seni sudah selalu menyimpan pola yang koheren, dan misi pendekatan historis adalah mengeksplisitkan dan mengartikulasikan pola-pola semacam ini. Amat disayangkan bahwa upaya yang diberikan Levinson tidak semulus itu. Tetap ada karya seni yang menjadi terlalu luas dan 'liar' meski dalam kategori yang jauh lebih sedikit. Sejarah ternyata menyimpan titik-titik ambigu yang tidak memberi batasan yang jelas antara karya seni dan melakukan pekerjaan sehari-hari, misalnya. ${ }^{20}$ 
Di titik inilah Carroll masuk dengan optimismenya dan memberikan sumbangan gagasan untuk menyelesaikan masalah akut yang menjangkiti estetika tersebut. Pendekatan yang diambil Carroll, sebagaimana yang akan dilihat berikut ini, adalah sebuah bauran antara pengalaman estetik dan elemen historis. Carroll memberi nama alur argumentasinya historical narrative (narasi historis), dan upaya ini didasarkan pada misi utama, dalam terang Carroll, dari filsafat seni: " $[\mathrm{t}]$ he task of the philosophy of art, first and foremost is that of handling such radical mutation [of an artwork]" (tugas utama filsafat seni, yang paling pertama dan utama, adalah untuk menangani mutasi radikal [karya seni] semacam ini). ${ }^{21}$ Meskipun demikian, sejak awal Carroll sudah mencurigai sisi problematis definisi, sehingga dengan tegas Carroll menyatakan bahwa "in contrast to definitionalists metaphysics is not my concern [...] epistemology is" (berlawanan dengan para definisionalis - metafisika bukanlah perhatian saya [...] melainkan epistemologi). ${ }^{22}$

Pemaknaan Ulang Pengalaman Estetis sebagai Apresiasi Desain dan Elemen Historis

Ada perlunya bagi para pengkaji estetika melihat alasan di balik kemunculan pengalaman estetis sebagai jangkar definisi karya seni, sebelum membahas dengan lebih spesifik tentang apa yang sebenarnya diinginkan oleh Noël Carroll dengan narasi historisnya. Ini berarti orang tidak bisa lepas dari abad kedelapan belas, abad kelahiran estetika. Demikian juga tidak bisa disangkal peran A.G. Baumgarten dalam membidani lahirnya bidang kajian yang sangat problematis ini. Bahwa estetika akhirnya menjadi sebuah cara untuk menentukan muatan seni murni dalam sebuah karya adalah hal yang mungkin tidak ada di kepala Baumgarten saat ia menulis Aesthetica. Dan sekali lagi, alasan kehadiran estetika dengan seni sebagai objek formalnya dalam peta sejarah filsafat mungkin tidak lebih dari 'kebetulan' atau 'kecelakaan'.

Christoph Menke dapat memberikan penjelasan yang sangat meyakinkan tentang mengapa sang "anak yang tidak diduga-duga ini" lahir pada 1750. Baumgarten sebenarnya membaptis estetika sebagai "the science of sensuous knowledge" (ilmu tentang pengetahuan inderawi). ${ }^{23}$ Menke memberikan catatan bahwa estetika di tangan Baumgarten adalah sebuah cara untuk mengetahui/mengenali (probo cognoscere) hal-hal yang 
tidak diketahui dengan rasio. Kebetulan dalam disertasinya, Meditationes philosophicae de nonnulis ad poema pertinentibus, Baumgarten menggunakan ilustrasi tentang kemampuan seorang seniman untuk mengetahui begitu saja "what is rightly and wrongly done" (apa yang dikerjakan dengan benar [atau] salah). ${ }^{24}$ Kemampuan ini disebut Baumgarten sebagai ars pulchre cogitandi - the art of beautiful thought (seni berpikir indah). Kemampuan semacam ini menandakan kapasitas kognitif unik manusia, sehingga untuk pertama kalinya dengan percaya diri Baumgarten mengatakan "we have to understand ourselves as subjects" (kita [manusia] harus memahami diri kita sebagai subjek). ${ }^{25}$ Bila demikian, ars pulchre cogitandi jelas bernuansa epistemologis, dan bukan pembahasan ala kadarnya tentang "yang indah".

Misi ini, sayangnya, gagal dijalankan dengan sempurna oleh Baumgarten, dan peran Kant adalah mengambilnya ke titik manakala pengetahuan murni bisa 'dipertemukan' dengan pengetahuan praktis, reinen Vernunft bertemu dengan practische Vernunft. Namun, Carroll mencatat bahwa David Hume sendiri melakukan sebuah kesalahan fatal: Hume membelokkan dan mereduksi misi yang digagas Baumgarten sebagai sekadar taste, lebih tepatnya, "good taste" yang sebenarnya sangat miskin dalam hal modalitas kata itu sendiri. ${ }^{26}$ Begitu miskinnya konsep taste ini, sehingga bila dibandingkan dengan dua konsep dari India dan Jepang, akan terlihat perbedaan yang begitu mencolok. India, misalnya, memiliki sembilan varian dari taste-nya Hume: śringāra, hāsya, karuna, raudra, vīra, bhayānaka, bībhatsa, adbhuta, dan sānta; sementara Jepang memiliki enam: mono no aware, okashi, yūgen, sabi, miyabi, dan wabi. ${ }^{27}$ Hume memberikan konsep taste sebagai bentuk ekivalen dari la goût dalam tradisi Perancis.

Secara tidak langsung, pembacaan Humean seperti ini membelokkan alur pembacaan Kritik der Urtheilskraft (Critique of Judgement atau Critique of the Power of Judgment ${ }^{28}$ ) menjadi kritik terhadap taste dalam konteks pemaknaannya yang paling peyoratif: tentang yang indah sebagai kenikmatan aristokratis dalam konteks menonton opera, misalnya. Keindahan yang dimaksud Kant adalah pulchre dalam ars pulchre cogitandi, dan bukan, menurut Carroll, "experience of pleasure merely projected onto the stimulus" (pengalaman kenikmatan yang diproyeksikan ke stimulus tertentu). ${ }^{29}$ Kastrasi makna semacam ini melemahkan argumen Kant yang sebenarnya ditujukan untuk menuntaskan misi yang diemban pendahulunya, Baumgarten. Pokok epistemologis yang terkikis inilah 
yang kemudian diangkat kembali dan diemansipasi oleh Carroll lewat jalur analitis, yang dilakukan dengan cara melakukan pembedahan argumen dengan menggunakan 'wasit' kondisi yang harus ada (necessary) untuk memenuhi kriteria sebuah konsep: bahwa upaya pendefinisian tersebut tidak bisa bersifat eksklusif; semua karya seni harus dapat dijelaskan dengan pendekatan yang diangkat oleh Carroll tersebut; dan gambit pembuka Carroll adalah menggunakan metode survei yang sama seperti yang ia lakukan dalam The Philosophy of Art, A Contemporary Introduction. Namun, kali ini ia memilih membedah langsung dari perspektif pengalaman estetis sebagai pintu masuk ke narasi historis.

Dengan melihat klasifikasi pengalaman estetik yang diajukan Carroll, dapat ditemukan bahwa pengklasifikasian Carrollian pun mengalami evolusi. Secara implisit dari bukunya tentang filsafat seni yang ditulis pada 1999 dapat diperkirakan bahwa Carroll belum mulai mengembangkan gagasannya tentang pengalaman estetis ke dalam kategori spesifik. Setidak-tidaknya saya menemukan bahwa baru dalam Beyond Aesthetics: Philosophical Essays yang merupakan kumpulan tulisan-tulisannya dari 1985-1999, Carroll mulai dengan empat macam catatan pengalaman estetis: pendekatan tradisional (traditional), pragmatik (pragmatic), alegoris (allegorical), dan deflasionaris (deflationary). Menariknya, dalam tulisannya di British Journal of Aesthetics pada 2002, "Aesthetic Experience Revisited", Carroll memangkas bagian alegoris dan mengubah nama tiga pendekatan sisanya: orientasi afeksi (affect-oriented), aksiologis (axiological), dan orientasi isi (content-oriented). Dalam kontribusinya di Contemporary Debates in Aesthetics and the Philosophy of Art yang pertama kali diterbitkan pada 2006, Carroll kembali menambahkan satu kategori, yakni pendekatan epistemik (epistemic approach) di samping tiga yang ia tulis sebelumnya. Di kontribusinya dalam Aesthetic Experience dua tahun kemudian (2008), Carroll hanya memfokuskan diri pada yang terakhir: pendekatan orientasi isi.

Dari perkembangan pemikiran Carroll tersebut masih bisa dilihat sebuah elemen yang selalu muncul, baik dengan nama deflasionaris maupun orientasi isi yang merupakan inti dari gagasan yang ditawarkan Carroll tentang narasi historis. Sebagaimana dapat diduga, pendekatan lainnya dalam label yang berbeda-beda tidak lain dari strategi analitis yang dilakukan Carroll untuk membuktikan bahwa semuanya memiliki satu kelemahan yang sama: semuanya tidak berlaku pada segala karya seni atau 
dengan kata lain, masih bersifat eksklusif. Dalam sumber-sumber yang disebutkan di atas, Carroll dengan meyakinkan telah membuktikan bahwa hanya pendekatan orientasi isi sanggup memenuhi syarat yang berlaku inklusif. Ini berarti bahwa Carroll menjangkar solusinya pada pengalaman estetis. Dari kelima mazhab yang sudah saya tunjukkan sebelumnya, hanya mazhab keempat yang masih menjanjikan bagi Carroll. Meski demikian, dengan pilihan seperti itu Carroll harus dapat menyelesaikan masalah yang paling mendesak: menutup kelemahan dari sikap mental tanpa-pamrih yang sangat kontroversial. Berikut ditelusuri misi emansipasi sikap mental estetis yang ditempuh Carroll.

Langkah berikut Carroll adalah melakukan investigasi masalahmasalah utama seputar sikap tanpa pamrih dalam mengalami karya seni. Carroll meminjam pendekatan ketiga, seni dan bentuk, dan mendapati bahwa kehadiran sebuah bentuk dalam karya seni tidak pernah tidak disengaja. Perlu sebuah kesengajaan bahkan untuk melakukan hal-hal yang tidak disengaja yang ditujukan sebagai sebuah karya seni. Bagi Carroll, ini jelas mungkin karena "[f]orms are selected because they are intended or designed to perform certain functions" (bentuk dipilih karena mereka memang sengaja dipilih atau didesain untuk menjalankan fungsi tertentu). ${ }^{30}$ Ini menjadi sangat penting karena " $[\mathrm{t}]$ he function of the form(s) of the artwork is to command our attention, to encourage us to take note of them, and perhaps to reflect on the way in which they mold our experience of them" (fungsi bentuk dalam sebuah karya seni adalah untuk menarik perhatian kita, untuk mengajak kita menaruh perhatian kita pada karyakarya itu, dan mungkin untuk merefleksikan leburan pengalaman kita dengannya). ${ }^{31}$

Posisi ini mengerucut pada kenyataan bahwa "in order to respond to art as art, one must appreciate its form" (untuk dapat mengapresiasi sebuah karya seni sebagai seni, seseorang harus [terlebih dahulu] mengapresiasi bentuknya). ${ }^{32}$ Ini berarti bahwa bentuk adalah titik mula dari kegiatan mengalami secara estetis; atau dengan kata lain, tidak mungkin ada pengalaman estetis tanpa keberadaan bentuk. Premis ketiga Carroll ini akan membawa pada kesimpulan pertama Carroll dalam mengemansipasi sikap ketanpa-pamrihan: "[a]rt appreciation is design appreciation - knowing how the work works, seeing how its parts are intended to function toward the realization of the point(s) or purpose(s) of the work" (apresiasi seni 
adalah apresiasi desain - mengetahui bagaimana sebuah karya bekerja, melihat bagaimana bagian-bagian dalam karya itu diarahkan ke sebuah realisasi hal-hal penting atau tujuan sebuah karya). ${ }^{33}$

Kesimpulan Carroll tersebut adalah sebuah argumen yang membuktikan bahwa telah terjadi kesalahan pemahaman tentang apa yang disebut sebagai pengalaman estetis. Lebih lanjut Carroll menekankan bahwa "[d]esign appreciation is one thing that people often mean by the phrases "aesthetic experience" (apresiasi desain adalah yang sesungguhnya dimaksud saat orang mengacu pada frasa "pengalaman estetik"). Mengapresiasi desainlah yang sebenarnya kita lakukan saat kita mengalami karya seni: “[w]e are simply concerned with how it works" (kita hanya mengarahkan seluruh perhatian kita pada cara karya itu bekerja). Bagi Carroll, inilah cara orang bekerja dalam mengalami sebuah karya seni. Dan ini berarti bahwa pengalaman estetis adalah "attention to and contemplation of the design of the work, including features such as unity and complexity" (perhatian pada dan kontemplasi terhadap desain karya tersebut, termasuk fitur-fitur seperti kesatuan dan kompleksitas). ${ }^{34}$

Carroll selanjutnya mempertegas apa yang ia maksud dengan mengapresiasi desain, dengan mengatakan bahwa setidak-tidaknya ada dua hal yang akan dilakukan seorang pengamat: (1) "attend to the structure or form of the artwork" (menaruh perhatian pada struktur atau bentuk karya seni), dan (2) "detection of the aesthetic and expressive qualities of an artwork" (deteksi kualitas estetis dan ekspresif karya seni). ${ }^{35}$ Di sini Carroll merinci lebih lanjut sambil menghidupkan ulang konsep aisthesis yang diangkat oleh Baumgarten dan yang digali dari Aristoteles. Carroll kembali mempertajam argumennya tentang apresiasi desain dalam artikelnya "Aesthetic Experience Revisited", ketika menegaskan bahwa "the form of an artwork [is] the assemble of choices intended to realize the point or the purpose of an artwork" (bentuk karya seni [adalah] gabungan pilihan yang ditujukan untuk merealisasikan hal-hal penting atau tujuan karya seni). ${ }^{36}$

Dalam "Aesthetic Experience: A Question of Content", Carroll memperjelas apa yang ia maksud sebagai elemen aisthesis: "aesthetic properties" atau ciri-ciri estetis. Lebih lanjut, Carroll akhirnya memasukkan unsur penting yang menurutnya melegitimasi label estetika konstruksi filosofis yang dibangunnya: alam, dan bagi Carroll unsur apresiasi desain dan ciri-ciri estetis dapat diterapkan dengan mudah saat 'melantik' alam 
menjadi sebuah karya seni. Bedanya, unsur-unsur fungsinya tidak hilang: "inasmuch as form is to be understood functionally, we can note an analogous way of engaging nature to apprehending the formal design of artworks" (dalam konteks bentuk dipahami secara fungsional, kita dapat menemukan analogi yang serupa dalam menyingkap desain formal yang biasa kita temukan dalam karya seni) $\cdot{ }^{37}$ Seakan-akan memberi kesimpulan yang tegas tentang apa itu pengalaman estetis, dalam "Aesthetic Experience, Art and Artists" Carroll mengatakan bahwa "[a]n experience of an artwork $[. .$.$] is aesthetic if the content of the experience is aesthetic - a matter of$ formal, expressive, or otherwise aesthetic properties and relations - and if that content is negotiated in the appropriate or correct manner" (sebuah pengalaman akan karya seni [...] disebut estetik bila isinya estetik - [dalam arti] isi tersebut menyangkut ciri-ciri dan relasi-relasi formal, ekspresif dan ciri-ciri estetik lainnya - [dan] jika isi tersebut dinegosiasikan dengan cara yang tepat dan sesuai). ${ }^{38}$

Agar dapat sepenuhnya memahami apa yang ditawarkan Carroll, akan dilihat kembali sisi historis yang merupakan bagian kedua dari narasi historis Carrollian. Di atas telah dilihat bagaimana Carroll memperbaiki ketanpapamrihan dalam pendekatan pengalaman estetis, namun ia tetap berpendapat bahwa ada satu elemen lagi yang mesti dituntaskan sebelum sebuah karya dikategorikan sebagai karya seni: elemen historis. Carroll menjelaskan bahwa " $[\mathrm{t}]$ he point of an identifying narrative is to situate a candidate for art status in the history of art in such way that the work can be placed as an intelligible contribution to the tradition" (pokok penting mengidentifikasi narasi adalah untuk menempatkan sebuah kandidat karya seni di dalam deretan sejarah seni sedemikian sehingga karya tersebut dapat memberikan kontribusi yang jelas pada tradisi). ${ }^{39}$ Lebih jauh lagi, Carroll mengatakan bahwa karya-karya yang gagal memenuhi kriteria, terutama elemen historis, tidak bisa dianggap karya seni, dan karya seperti ini harus ditolak bila ia "factually flawed" atau cacat secara factual, dan "revert to anachronistic" (mengacu pada hal-hal yang bersifat anakronistis). Sebuah karya, dalam pemikiran Carroll, harus memiliki keakuratan historis (bistorical accuracy) setajam mungkin.

Kedua hal ini, apresiasi desain dan elemen historis adalah inti dari posisi yang ditawarkan Carroll, yakni narasi historis, dan sekaligus ini adalah tolak ukur dari apa yang disebut karya seni. Inilah solusi yang 
diajukan Carroll, yakni sebuah pendekatan komprehensif yang bersifat inklusif terhadap karya seni. Selanjutnya adalah apa yang akan dilakukan dengan solusi ini. Carroll dalam On Criticism memberikan jawaban yang sangat tegas: gunakanlah! Narasi historis adalah sebuah kerangka kerja yang sudah dibuktikan secara analitis, dan yang sekarang harus diuji coba di dunia nyata.

Lebih tepatnya, Carroll mengatakan dengan sangat sederhana: buatlah kritik tentang karya seni. Lagi pula, kritik berasal dari bahasa Yunani, kritikos, yang berarti menghakimi, dan bisa bersifat positif dan negatif. ${ }^{40}$ Bagi Carroll, seorang kritikus adalah "someone who is capable not only in evaluating artworks, but who is also expert in the sense that [the person] is adept at backing those verdicts up with reasons" (seorang kritikus adalah orang yang tidak hanya mampu dalam mengevaluasi karya seni, tetapi juga orang yang ahli dalam konteks tersebut dan yang bisa memberikan dasar rasionalnya). ${ }^{41}$

Orang bisa bertanya mengapa evaluasi menjadi bagian penting dari pemikiran Carroll dalam tataran praksis. Sebabnya ialah, dalam mengevaluasi karya seni ini kritik karya seni narasi historis Carrollian mewujud dalam apresiasi desain yang diperkaya dengan deteksi ciri-ciri estetis dan ketepatan historis bekerja secara nyata. Carroll mempergunakan kegiatan evaluasi seni sebagai semacam "arena tarung" untuk membuktikan inklusivisme pendekatan yang ditawarkannya. Ia mengatakan bahwa "the primary function of criticism is to say what is good in a work" (fungsi paling utama dari kritik [seni] adalah untuk mengatakan apa yang baik dari sebuah karya). ${ }^{42}$ Baginya, mengkritik karya seni bukanlah perkara "membantai dan mencincang" sebuah karya, apalagi dasar yang dipergunakan hanyalah preferensi sang 'kritikus'. Mengevaluasi karya seni, lanjut Carroll, adalah sebuah "phenomenon of agreement" (fenomenon kesepakatan), dan bukan sebaliknya. ${ }^{43}$

Pada bagian ini perlu dilihat sekilas bagaimana Carroll sendiri menerapkan prinsip yang dilahirkan dan dibesarkannya. Dalam satu bidang kajian yang juga ditekuninya, yakni horor, atau lebih tepat art-horor, ditunjukkan bagaimana apresiasi desain bekerja. Ia mengatakan bahwa "rather than characterizing art-horror solely on the basis of our own subjective responses, we can ground our conjectures on observations of the way in which characters respond to the monsters in works of horror" 
(daripada menarik ciri-ciri seni-horor hanya berdasarkan respons subjektif kita, kita dapat melandasi konjektur yang kita kemukakan pada pengamatan dari reaksi pengamat terhadap monster yang ada di karya-karya horor). Lewat apresiasi semacam ini, lanjut Carroll, orang akan sampai pada temuan bahwa ada dua elemen penting yang dipercaya pengamat tentang monster seperti Drakula, misalnya, "that the monster is regarded as threatening and impure" (bahwa monster semacam ini dianggap mengancam dan kotor). Kedua anggapan ini akan berhubungan langsung dengan dua macam emosi dalam diri pengamat, yakni dua buah pengalaman estetis, bahwa ancaman akan berhubungan dengan emosi ketakutan, dan kotor akan berhubungan dengan emosi rasa jijik. Ini berarti bahwa "[a]rt-horror requires evaluation both in terms of threat and disgust" (seni horror membutuhkan kedua macam evaluasi, baik dalam hal ancaman dan rasa jijik). ${ }^{44}$

Satu contoh lagi, masih dari bidang kajian Carroll, ialah film bioskop, yang mengilustrasikan bagaimana konteks historis menjadi bagian penting dalam sebuah evaluasi karya seni yang sifatnya ditujukan ke publik. Dalam The Philosophy of Motion Pictures Carroll mengatakan bahwa "evaluating some motion pictures may require summing up the value of the movie [...] plus some estimates of the social values of the purposes that category of moving image usually serves" (mengevaluasi film komersil membutuhkan sebuah upaya menyimpulkan nilai sebuah film [...] ditambah dengan perkiraan tentang nilai-nilai sosial dari tujuan yang biasa dijadikan landasan dari kategori gambar bergerak). Film bioskop, lanjutnya, memberi tekanan lebih pada kebutuhan-kebutuhan akan perkembangan peradaban (civilizational interests) daripada sekadar menghibur. ${ }^{45}$ Film publik yang sekadar menghibur - kalau saya boleh parafrasekan gagasan Carroll kurang bermuatan artistik dibanding film yang tanggap terhadap nilai-nilai lebih tinggi yang dibuktikan secara historis, seperti nilai peradaban. Sekali lagi, hal ini relevan saat orang membahas tentang film-film yang memang ditujukan untuk konsumsi massal.

\section{Simpulan}

Lepas dari strategi yang dipergunakan Carroll untuk "menjaring pengikut", setidak-tidaknya ada pokok yang sangat penting bisa diambil, yakni bahwa mencari makna sebuah karya bukanlah sebuah prioritas. Carroll sudah membuktikan bahwa selama upaya ini hanya berhenti pada mencari 
makna, maka akan terlalu banyak upaya pendefinisian yang tumpang tindih. Orang tidak boleh lupa bahwa pendekatan yang dipergunakan Carroll tidak bersifat metafisis, melainkan epstemologis. Orang juga tidak boleh lupa bahwa dasar yang dipergunakan Carroll adalah pengalaman estetis, selain elemen historis, dan tidak akan ada pengalaman estetis tanpa intensi sang seniman. Dan intensi erat kaitannya dengan tujuan. Tidak bisa dilupakan bahwa Carroll menempatkan tujuan sebagai salah satu elemen penting pendefinisian sebuah karya.

Atas dasar itu, mungkin memang benar bahwa "Apa itu seni?" akan selalu susah dijawab. Mungkin kelompok Neo-Wittgensteinian akan merasa di atas angin, karena yakin bahwa seni tidak akan bisa didefinisikan. Akan tetapi, di sini juga sudah dilihat bagaimana Carroll lebih berpendapat bahwa seni harus bisa dipergunakan sebagai sebuah sarana untuk mendefinisikan realitas, memberikan abstraksi atau abstraksi atas abstraksi, dan seterusnya. Bila pertanyaan "Apa itu seni?" terasa begitu susah dijawab, mungkin karena muatan ontologis atau metafisis lebih bersifat spekulatif, dan akhirnya menjadi ganjalan serius dalam memetakan karya seni. Bisa jadi yang dibutuhkan bukanlah pertanyaan "Apa itu seni?”, tetapi, dalam terang pemikiran Carroll saat membahas pengalaman estetis, pertanyaan yang lebih relevan: "Untuk apa seni?"

\section{Bibliography}

Carroll, Noël. The Philosophy of Art, A Contemporary Introduction. London: Routledge, 1999.

. Beyond Aesthetics: Philosophical Essays. Cambridge: Cambridge University Press, 2003.

. On Criticism. New York: Routledge, 2009.

. The Philosophy of Motion Pictures. Oxford: Blackwell Publishing,

2008

"Aesthetic Experience Revisited". British Journal of Aesthetics. Vol. 42. Nr. 2. April, 2002

"The Nature of Horror". The Journal of Aesthetics and Art Criticism. Vol. 46. Nr.1 (Fall, 1987). 
"Aesthetic Experience, Art and Artists". Aesthetic Experience. Richard Shusterman \& Adele Tomlin (Eds.). New York: Routledge, 2008.

"Aesthetic Experience: A Question of Content". Contemporary Debates in Aesthetics and the Philosophy of Art. Kieran, Matthew (Ed.). Oxford: Blackwell, 2006.

Higgins, Kathleen. "Refined Emotion in Aesthetic Experience". Aesthetic Experience. Richard Shusterman \& Adele Tomlin (Eds.). New York: Routledge, 2008.

Levinson, Jerrold. "Philosophical Aesthetics: An Overview". The Oxford Handbook of Aesthetics. Jerrold Levinson (Ed.). Oxford: Oxford University Press, 2003.

Menke, Cristoph. "The Dialectics of Aesthetics". Aesthetic Experience. Richard Shusterman \& Adele Tomlin (Eds.). New York: Routledge, 2008.

Nietzsche, Friedrich. A Genealogy of Morals. Vol. X. William A. Hausemann (Trans.). The Works of Friedrich Nietzsche. New York: The Macmillan Company, 1897.

\section{Endnotes:}

1 Dalam The Oxford Handbook of Aesthetics, Levinson memberikan definisi estetika sebagai sebuah cabang filsafat yang secara konseptual dan teoretis menelaah seni serta pengalaman estetik. Di sini dapat dilihat bagaimana seni memainkan peranan yang sangat fundamental dalam estetika. Lih. Jerrold Levinson, "Philosophica Aesthetics: An Overview" dalam Jerrold Levinson (Ed.), The Oxford Handbook of

2 Noël Carroll, The Pbilosophy of Art, A Contemporary Introduction (London: Routledge 1999) 19.

3 Ibid., 20.

4 Ibid., 25.

5 Ibid., 60-61.

6 Ibid., 70 dan 75.

7 Ibid., 103.

8 Ibid., 109.

9 Ibid. 126.

10 Ibid., 156-157.

11 Ibid., 159. 
12 Friedrich Nietzsche, $A$ Genealogy of Morals. Vol. X dari William A. Hausemann (Transl.), The Works of Friedrich Nietzsche (New York: The Macmillan Company, 1897) 139. Buku diperoleh dari hasil digitalisasi oleh Standford University Libraries https://archive.org/stream/Genelogy/OrMorals/GoogleGenOptimized\#page/ n29/mode/2up. (access 15.09.2016).

13 Carroll, The Philosophy of Art., op.cit., 160.

14 Ibid., 164.

15 Ibid., 177.

16 Ibid., 179.

17 Ibid., 213.

18 Ibid., 232.

19 Ibid., 242.

20 Ibid., 247.

21 Noël Carroll, Beyond Aesthetics: Philosophical Essays (Cambridge: Cambridge University Press, 2003) 104.

22 Ibid., 118.

23 Cristoph Menke, "The Dialectics of Aesthetics" dalam Richard Shusterman dan Adele Tomlin (Eds.), Aesthetic Experience (New York: Routledge, 2008) 60.

24 Ibid., 61.

25 Ibid., 62

26 Noël Carroll, On Criticism (New York: Routledge, 2009) 155

27 Kathleen Higgins, "Refined Emotion in Aesthetic Experience" dalam Richarc Shusterman dan Adele Tomlin (Eds.), Aesthetic Experience (New York: Routledge, 2008) 111.

28 Judul yang pertama dipergunakan dalam terjemahan James Creed Meredith, sementara yang kedua dalam terjemahan Paul Guyer.

29 Carroll, On Criticism, op.cit., 158.

30 Carroll, The Philosophy of Art, op.cit., 145.

31 Ibid., 147.

32 Ibid., 148.

33 Ibid., 150.

34 Ibid., 188-189.

35 Carroll, Beyond Aesthetics, op.cit., 59.

36 Noël Carroll, "Aesthetic Experience Revisited" dalam British Journal of Aesthetics. Vol. 42. Nr. 2 (April, 2002).

37 Noël Carroll, "Aesthetic Experience: A Question of Content" dalam Matthew Kieran (Ed.), Contemporary Debates in Aesthetics and the Philosophy of Art (Oxford:

38 Noël Carroll, "Aesthetic Experience, Art and Artists" dalam Richard Shusterman dan Adele Tomlin (Eds.), Aesthetic Experience (New York: Routledge, 2008) 159.

39 Carroll, Beyond Aesthetics, op.cit., 109.

40 Carroll, On Criticism, op.cit., 14.

41 Ibid., 15.

42 Ibid., 36. Tekanan dari saya. 
43 Ibid., 37.

44 Noël Carroll, "The Nature of Horror" dalam The Journal of Aesthetics and Art Criticism. Vol.46. Nr.1 (Fall, 1987) 53-55.

45 Noël Carroll, The Pbilosophy of Motion Pictures (Oxford: Blackwell Publishing, 2008) 222-223. 